\title{
DNA Damage and Lung Cancer Risk in Tobacco Smokers
}

\author{
Armelle Munnia, Filippo Cellai and Marco EM Peluso* \\ Department of Cancer Risk Factor, ISPO-Cancer Prevention and Research Institute, Italy
}

Submission: March 01, 2017; Published: May 02, 2017

*Corresponding author: Marco EM Peluso, Department of Cancer Risk Factor, Cancer Prevention and Research Institute, Italy, Fax: 3905-532697879; Email: m.peluso@ispo.toscana.it

\begin{abstract}
Purpose: Lung cancer is currently the leading cause of cancer death in the world. Although the rates of lung cancer mortality have started to decrease in most industrialized countries, the long time lag between the peak of cigarette consumption and lung cancer development will assure a long life for the epidemic. We reviewed the four epidemiological studies that have examined the dose-response relationship of polycyclic aromatic hydrocarbons (PAH)-related DNA adducts with lung cancer using 32P-postlabeling by pooled- or meta-analytic approach. Our purpose was to evaluate if the presence of high levels of PAH-related adducts in peripheral blood are associated with increased risk of lung cancer in tobacco smokers.

Results: Meta-analyses of case-control and cohort studies with a final data set containing data for 1,028 lung, oral and bladder cancer patients and 1,084 controls showed higher frequency of DNA damage in smokers in respect to referents. When only lung cancer was considered, smokers were having 79\% (95\% Confidence Interval 0.33-1.25) higher levels of PAH-related adducts as compared to controls. Pooled and meta-analysis of longitudinal prospective studies, were the measurement of adducts was performed in peripheral blood that was collected years before cancer onset, confirmed that the production of PAH-related DNA adducts was associated with lung cancer in smokers with an overall estimate of 34\% increase as compared to referents (95\% Confidence Interval 1.10-1.64).
\end{abstract}

Conclusion: Pooled and meta-analysis indicate that smokers with greater levels of DNA damage have increased risk of lung cancer. In prospective longitudinal studies, the overall excess of adducts in smokers with lung cancer in respect to controls supports the value of adducts as a predictive biomarker, that might be used to select high risk subjects for cancer screening programs.

Keywords: DNA adducts; Lung cancer; Risk

\section{Introduction}

Lung cancer is currently the leading cause of cancer death in the world [1]. In the past century, lung cancer was extremely rare and represented $<1 \%$ of all cancer cases [2,3], whereas becomes the leading cause of cancer death in out rime [1]. During the last decades, the role of tobacco smoking in lung cancer etiology has accumulate [4,5]. Although the rates of lung cancer mortality have started to decrease in Western countries [1], smoking attributable deaths are even projected to increase due to the surge in tobacco consumption among young people [6]. The low-dose computed tomography screening, along with smoking cessation programmes, appears to be one of the potentially most useful strategies able to improve the current poor survival associated with lung cancer [7]. Nevertheless, additional efforts for early detection of lung cancer, in particular, molecular biomarkers are still necessary, which may improve the selection of individuals for screening programs [8].
Tobacco smoke contains more than 3,500 chemicals [4], of which 73 tumor-initiating carcinogens either in humans and animal models, including some polycyclic aromatic hydrocarbons (PAHs) [4], compounds capable to bind DNA covalently, inducing PAH-related DNA adducts [9-11]. DNA adducts, if unrepaired, may lead to mutations in tumor suppressors and oncogenes [12]. PAH-related DNA adducts represent an integrated biomarker of environmental exposure to carcinogenetic compounds [13-15] and reflect the capability of each individual to metabolically activate carcinogens and repair DNA damage [16-19]. The levels of adducts in lung tissues have been shown to correlate with tobacco smoke intensity in a few investigations [11,15,20-22]. Nevertheless, there were the exception of the studies of Van Schooten et al. [23], and Chen et al. [24]. Wiencke et al. [25], and Peluso et al. [26], demonstrated that peripheral blood is a valid surrogate to estimate adduct burden in respiratory 
tissue. An association of PAH-related adducts with aberrant DNA methylation has been even shown [27]. The occurrence of genotoxic events with the induction of various cancers, including lung cancer, has prompt interest in DNA adduct dosimetry studies in humans for studying the predictivity of PAH-related DNA adducts for human cancer [12]. The central question is whether DNA damage, in the lung tissue, truly cause cancer. If so, it might be employed such as molecular biomarkers of lung cancer risk. Conversely, whether the base alterations are caused by tumor progression, and thereby they are just a bystander, so their frequency would not predict cancer risk.

In the current study, we have reviewed the epidemiological studies that have examined the dose-response relationship of PAH-related DNA adducts with cancer using 32P-postlabeling [28-30], by pooled- or meta-analytic approach [31-33]. Most of the dosimetry studies were conducted analyzing blood cells, the easiest method that provides a large amount of DNA [28], which is widely considered a reliable surrogate target of bronchial mucosa [25-26]. Our purpose was to evaluate if the presence of high levels of PAH-related DNA adducts in peripheral blood are associated with increased risk of lung cancer in tobacco smokers, prompting its use in screening programs.

\section{Results and Discussion}

In the present review, we have analyzed the four investigations that have evaluated the association between PAHrelated DNA adducts and human cancer in peripheral blood by pooled- or meta-analytic approach [31-34].

\section{Case-Control and Cohort Studies}

In 2003, Veglia et al. [34] performed a meta-analysis of seven studies that investigated the association of PAH-related DNA adducts with human cancer [33,35-41]. Lung, oral and bladder cancer patients were included. Six investigations analysed adducts in peripheral blood and one in lung tissue. Six were case-controlled studies and one was a case-control study on lung cancer nested within a cohort. The data set included 691 cancer patients and 632 healthy controls. In that meta-analysis, smoker cases had $83 \%$ greater levels of adducts than controls (95\% confidence interval (C.I.), 0.44-1.22). Conversely, findings were negative or contradictory in ex-smokers and non-smokers. In 2008, Veglia et al. [32], added two cohort studies [33-42], to the data set of the previous meta-analysis [34], obtaining 1,028 cancer cases and 1,084 controls. Even in this case, the levels of PAH-related DNA adducts were associated with the occurrence of various cancer (lung, bladder and oral mucosa), with smokers having on average $73 \%$ greater amounts of adducts as compared to controls. When only lung cancer disease was evaluated, a higher frequency of DNA damage was found in smokers that were having $79 \%$ (95\% C.I. 0.33-1.25) greater levels of PAHrelated adducts as compared to referents. Conversely, none associations or contradictory findings were observed among exsmokers and non-smokers.
In 2006, Bak et al. [33], examined four lung cancer casecontrol study [37-40], and two cohort studies [33,36], where the formation of PAH-related DNA adducts was measured in case controlled and cohort studies. In this report, the meta-analysis was restricted to lung cancer and smokers, with a final data set of 397 cancer cases and 374 controls. In that study, Bak et al. found a difference between lung cancer patients and controls with cases having 78\% (95\% C.I. 0.29-1.27) higher levels of adducts as compared to controls.

\section{Longitudinal Prospective Studies}

In 2008, Veglia et al. [32], performed a pooled analysis of three longitudinal prospective studies [33,36,42], where all the biological samples were collected years before lung cancer onset. In the data set were included: a) one study from the Danish prospective Diet, Cancer and Health cohort study with a case-cohort design [33], b) a nested case-control study within the European EPIC cohort, including France, Denmark, Germany, Greece, Italy, Netherlands, Norway, Spain, Sweden, United Kingdom [42], and c) a nested case-control study within the Physicians' Health Study [36]. The final data set consists of 446 lung cancer cases and 1,498 controls having a follow-up period of 51-137 months. In this study, the levels of PAH-related DNA adduct were higher in smokers who developed lung cancer. An Odds Ratio of 8.38 (95\% C.I. 6.15-11.41) was indeed found in lung cancer smoker patients as compared to non-smokers. An increase of $14 \%$ per unit standard deviation supported the predictive value of adducts for lung cancer. In 2014, Gilberson et al. [31], performed a meta-analysis on DNA adducts and lung cancer from four longitudinal prospective studies. In this metaanalysis, the nested case-controlled investigation conducted within the Spanish EPIC study [31], was added to the data set, which was previously considered in the pooled analysis of Veglia et al. [32]. The final data set was of 2,341 subjects with a follow-up range of 51-137 months. In this study, the generation of adducts was associated with lung cancer in smokers with an overall estimate of $34 \%$ increase as compared to controls (95\% C.I. 1.10-1.64). No associations or contradictory findings were detected in ex-smokers and non-smokers.

Taken together, there is an agreement with the proposition that increased levels of PAH-related DNA adducts are associated with lung cancer for individuals with high exposure to tobacco smoke carcinogens. Nevertheless, this depends on whether the adducts cause lung cancer or the generation of DNA damage is influenced by early effects of cancer itself. The interpretation of the meta-analyses are indeed limited by the fact that in casecontrol studies the levels of biomarker may reflect the cancer disease rather than the etiology. However, two exceptions are represented by the studies of Veglia et al. [32] and Gilberson et al. [31]. The importance of these reports rests on the measurement of PAH-related adducts in peripheral blood that was collected years before cancer onset, thus ruling out the possibility that the greater amounts of adducts were due to metabolic changes 
associated with an already existing lung cancer. Thus, prospective longitudinal studies suggest that increased levels of PAH-related DNA damage in smoker that will develop lung cancer can be considered a cancer risk factor, because if unrepaired, adducts may lead to mutations and ultimately trigger carcinogenesis.

\section{Conclusion}

Pooled and meta-analysis indicate that smokers with greater levels of DNA damage have increased risk of lung cancer. These findings corroborate the epidemiologic data supporting the association of lung cancer with smoking habit. In prospective longitudinal studies, the overall excess of adducts in smokers with lung cancer in respect to controls supports the value of adducts as a predictive biomarker, that might be used to select high risk subjects for cancer screening programs. We may argue that phenotypes characterized by high levels of PAHrelated adducts may arise in susceptible individuals at high risk of lung cancer as consequence of disorders in regulatory circuitry that act to maintain cell homeostasis and DNA integrity after carcinogen exposure to tobacco smoke constituents [17]. However, it should be also relevant to consider for screening programs other biomarkers such as measurements of epigenetic alterations [43], as well as DNA damage at sequence level [44].

\section{Acknowledgement}

This study was partially supported by the "Associazione Italiana per la Ricerca sul Cancro", Milan, Italy, and the "Istituto Toscano Tumori", Florence, Italy.

\section{References}

1. Islami F, Torre LA, Jemal A (2015) Global trends of lung cancer mortality and smoking prevalence. Translational lung cancer research 4(4): 327-338.

2. Wynder EL, Hoffmann D (1994) Smoking and lung cancer: scientific challenges and opportunities. Cancer Res 54(20): 5284-5295.

3. Herbert H (1905) A Case of Primary Carcinoma of the Lung. California state journal of medicine 3(5): 143-144.

4. IARC (2004) Tobacco smoke and involuntary smoking. IARC Monogr Eval Carcinog Risks Hum 83:1-1438.

5. Mathers CD, Loncar D (2006) Projections of global mortality and burden of disease from 2002 to 2030. PLoS Med 3(11): e442.

6. Aberle DR, Adams AM, Berg CD, Black WC, Clapp JD, et al. (2011) Reduced lung-cancer mortality with low-dose computed tomographic screening. N Engl J Med 365(5): 395-409.

7. Field JK, Devaraj A, Duffy SW, Baldwin DR (2016) CT screening for lung cancer: Is the evidence strong enough? Lung cancer 91: 29-35.

8. Munnia A, Saletta F, Allione A, Piro S, Confortini M, et al. (2007) 32P-Post-labelling method improvements for aromatic compoundrelated molecular epidemiology studies. Mutagenesis 22(6): 381-385.

9. Palli D, Saieva C, Munnia A, Peluso M, Grechi D, et al. (2008) G: DNA adducts and PM (10) exposure in traffic-exposed workers and urban residents from the EPIC-Florence City study. Sci Total Environ 403(13): 105-112.
10. Peluso MEM, Munnia A (2014) DNA adducts and the total sum of at-risk DNA repair alleles in the nasal epithelium, a target tissue of tobacco smoking-associated carcinogenesi. Toxicol Res 3: 42-49.

11. Phillips DH, Venitt S (2013) DNA and protein adducts in human tissues resulting from exposure to tobacco smoke. Int J Cancer 131(12): 27332753.

12. Peluso M, Merlo F, Munnia A, Bolognesi C, Puntoni R, et al. (1996) (32) P-postlabeling detection of DNA adducts in peripheral white blood cells of greenhouse floriculturists from western Liguria, Italy. Cancer Epidemiol Biomarkers Prev 5(5): 361-369.

13. Merlo F, Bolognesi C, Peluso M, Valerio F, Abbondandolo A (1997): Airborne levels of polycyclic aromatic hydrocarbons: 32P-postlabeling DNA adducts and micronuclei in white blood cells from traffic police workers and urban residents. J Environ Pathol Toxicol Oncol 16(2-3): 157-162.

14. Peluso M, Amasio E, Bonassi S, Munnia A, Altrupa F, et al. (1997) Detection of DNA adducts in human nasal mucosa tissue by 32P-postlabeling analysis. Carcinogenesis 18(2): 339-344.

15. Peluso M, Srivatanakul P, Jedpiyawongse A, Sangrajrang S, Munnia A, et al. (2013) Aromatic DNA adducts and number of lung cancer risk alleles in Map-Ta-Phut Industrial Estate workers and nearby residents. Mutagenesis 28(1): 57-63.

16. Peluso ME, Munnia A, Srivatanakul P, Jedpiyawongse A, Sangrajrang S, et al. (2013) DNA adducts and combinations of multiple lung cancer atrisk alleles in environmentally exposed and smoking subjects. Environ Mol Mutagen 54(6): 375-383.

17. Peluso M, Munnia A, Piro S, Armillis A, Ceppi M (2010) Smoking, DNA adducts and number of risk DNA repair alleles in lung cancer cases, in subjects with benign lung diseases and in controls. J Nucleic Acids 2010: 386798.

18. Agudo A, Peluso M, Sala N, Capella G, Munnia A, et al. (2009) Aromatic DNA adducts and polymorphisms in metabolic genes in healthy adults: findings from the EPIC-Spain cohort. Carcinogenesis 30(6):968-976.

19. Phillips DH, Hewer A, Martin CN, Garner RC, King MM (1998) Correlation of DNA adduct levels in human lung with cigarette smoking. Nature 336(6201): 790-792.

20. Phillips DH, Schoket B, Hewer A, Bailey E, Kostic S, et al. (1990) Influence of cigarette smoking on the levels of DNA adducts in human bronchial epithelium and white blood cells. Int J Cancer 46(4): 569575 .

21. Dunn BP, Vedal S, San RH, Kwan WF, Nelems B (1991) DNA adducts in bronchial biopsies. Int J Cancer 48(4): 485-492.

22. Van Schooten FJ, Hillebrand MJ, van Leeuwen FE, Lutgerink JT, van Zandwijk N, et al. (1990) Polycyclic aromatic hydrocarbon-DNA adducts in lung tissue from lung cancer patients. Carcinogenesis 11(9):1677-1681.

23. Chen SY, Wang LY, Lunn RM, Tsai WY, Lee PH (2002) Polycyclic aromatic hydrocarbon-DNA adducts in liver tissues of hepatocellular carcinoma patients and controls. Int J Cancer 99(1): 14-21.

24. Wiencke JK, Kelsey KT, Varkonyi A, Semey K, Wain JC (1995) Correlation of DNA adducts in blood mononuclear cells with tobacco carcinogeninduced damage in human lung. Cancer Res 55(21): 4910-4914.

25. Peluso M, Neri M, Margarino G, Mereu C, Munnia A, et al. (2004) Comparison of DNA adduct levels in nasal mucosa, lymphocytes and bronchial mucosa of cigarette smokers and interaction with metabolic gene polymorphisms. Carcinogenesis 25(12): 2459-2465.

26. Tekpli X, Landvik NE, Anmarkud KH, Skaug V, Haugen A, et al. (2013) DNA methylation at promoter regions of interleukin $1 \mathrm{~B}$, interleukin 
6, and interleukin 8 in non-small cell lung cancer. Cancer Immunol Immunother 62(2): 337-345.

27. Peluso M, Hainaut P, Airoldi L, Autrup H, Dunning A, et al. (2005) Methodology of laboratory measurements in prospective studies on gene-environment interactions: the experience of GenAir. Mutat Res 574(1-2): 92-104.

28. Phillips DH, Arlt VM (2007) The 32P-postlabeling assay for DNA adducts. Nat Protoc 2(11):2772-2781.

29. Peluso M, Castegnaro M, Malaveille C, Talaska G, Vineis P, et al. (1990) 32P-postlabelling analysis of DNA adducted with urinary mutagens from smokers of black tobacco. Carcinogenesis 11(8):1307-1311.

30. Gilberson T, Peluso ME, Munia A, Lujan-Barroso L, Sanchez MJ, et al. (2014) Aromatic adducts and lung cancer risk in the European Prospective Investigation into Cancer and Nutrition (EPIC) Spanish cohort. Carcinogenesis 35(9): 2047-2054.

31. Veglia F, Loft S, Matullo G, Peluso M, Munnia A, et al. (2008) DNA adducts and cancer risk in prospective studies: a pooled analysis and a meta-analysis. Carcinogenesis 29(5): 932-936.

32. Bak H, Autrup H, Thomsen BL, Tjonneland A, Overvad K (2006) Bulky DNA adducts as risk indicator of lung cancer in a Danish case-cohort study. Int J Cancer 118(7):1618-1622.

33. Veglia F, Matullo G, Vineis P (2003) Bulky DNA adducts and risk of cancer: a meta-analysis. Cancer Epidemiol Biomarkers Prev 12(2):157160.

34. Peluso M, Airoldi L, Magagnotti C, Fiorini L, Munnia A (2000) White blood cell DNA adducts and fruit and vegetable consumption in bladder cancer. Carcinogenesis 21(2):183-187.

35. Tang D, Phillips DH, Stampfer M, Mooney LA, Hsu Y, et al. (2001) Association between carcinogen-DNA adducts in white blood cells and lung cancer risk in the physicians health study. Cancer Res 61(18): 6708-6712.

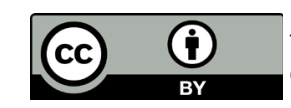

This work is licensed under Creative

Commons Attribution 4.0 Licens

DIO: 10.19080/IJCSMB.2017.2.555586
36. Tang D, Santella RM, Blackwood AM, Young TL, Mayer J, et al. (1995) A molecular epidemiological case-control study of lung cancer. Cancer Epidemiol Biomarkers Prev 4(4): 341-346.

37. Cheng YW, Chen CY, Lin P, Huang KH, Lin TS, et al. (2000) DNA adduct level in lung tissue may act as a risk biomarker of lung cancer. European journal of cancer 36(11): 1381-1388.

38. Hou SM, Yang K, Nyberg F, Hemminki K, Pershagen G, et al. (1999) Hprt mutant frequency and aromatic DNA adduct level in non-smoking and smoking lung cancer patients and population controls. Carcinogenesis 20(3): 437-444.

39. Vulimiri SV, Wu X, Baer-Dubowska W, Andrade M, Detry M, et al. (2000) Analysis of aromatic DNA adducts and 7,8-dihydro-8-oxo-2' deoxyguanosine in lymphocyte DNA from a case-control study of lung cancer involving minority populations. Mol Carcinog 27(4): 330.

40. Popp W, Schell C, Kraus R, Vahrenholz C, Wolf R, et al. (1993) DNA strand breakage and DNA adducts in lymphocytes of oral cancer patients. Carcinogenesis 14(11): 2251-2256.

41. Peluso M, Munnia A, Hoek G, Krzyzanowski M, Veglia F, et al. (2005) DNA adducts and lung cancer risk: a prospective study. Cancer Res 65(17): 8042-8048.

42. Peluso M, Bollati V, Munnia A, Srivatanakul P, Jedpiyawongse A, et al. (2012) DNA methylation differences in exposed workers and nearby residents of the Ma Ta Phut industrial estate, Rayong, Thailand. Int J Epidemiol 41(6): 1753-1760.

43. Peluso ME, Munnia A, Bollati V, Srivatanakul P, Jedpiyawongse A, et al. (2014) Aberrant methylation of hypermethylated-in-cancer-1 and exocyclic DNA adducts in tobacco smokers. Toxicol Sci 137(1): 47-54.

44. Brancato B, Munnia A, Cellai F, Ceni E, Mello T, et al. (2016) 8-0xo-7,8dihydro-2'-deoxyguanosine and other lesions along the coding strand of the exon 5 of the tumour suppressor gene P53 in a breast cancer case-control study. DNA research: an international journal for rapid publication of reports on genes and genomes 23(4): 395-402.

\begin{tabular}{l} 
Your next submission with Juniper Publishers \\
will reach you the below assets \\
- Quality Editorial service \\
- Swift Peer Review \\
- Reprints availability \\
- E-prints Service \\
- Manuscript Podcast for convenient understanding \\
- Global attainment for your research \\
- Manuscript accessibility in different formats \\
( Pdf, E-pub, Full Text, Audio) \\
- Unceasing customer service \\
Track the below URL for one-step submission \\
https://juniperpublishers.com/online-submission.php \\
\hline
\end{tabular}

